\title{
DISCUSSION
}

\section{DEVELOPING LEARNER AUTONOMY-BASED FOREIGN LANGUAGE PROFICIENCY ENHANCEMENT MODEL FOR VIETNAM'S PUBLIC OFFICIALS, CIVIL SERVANTS AND PUBLIC EMPLOYEES ${ }^{1}$}

\author{
Nguyen Ngoc Luu Ly* \\ Faculty of French Language and Culture, VNU University of Languages and International Studies, \\ Pham Van Dong, Cau Giay, Hanoi, Vietnam
}

Received 05 June 2018

Revised 20 July 2018; Accepted 23 July 2018

\begin{abstract}
Autonomy is a popular research theme among scholars worldwide. This article explains the selection, analysis, evaluation and deployment of learner autonomy model which is suitable for Vietnam's public officials, civil servants and public employees to acquire and master foreign languages who would benefit from the State-level research project $A$ study to develop foreign language proficiency enhancement models for public officials, civil servants and public employees in the Customs, Foreign Relations, Tourism and Border Guards sectors for public service delivery amidst the international integration trend in the Northwest conducted by ULIS-VNU under the Program "Science and Technology for sustainable development of the Northwest" coded KHCN-TB/13-18. The article also formulates recommendations on ways to improve foreign language proficiency for Vietnam's public officials, civil servants and public employees, considering that there is a need for innovation in foreign language teaching and learning methods in order to enable learners to use foreign languages at work effectively.
\end{abstract}

Keywords: model, foreign language proficiency, learner autonomy, public officials, civil servants, public employees

The State-level research project $A$ study to develop foreign language proficiency enhancement models for public officials, civil servants and public employees in the Customs, Foreign Relations, Tourism and Border Guards sectors for public service delivery amidst the international integration trend in the Northwest (hereafter referred to as the Project) conducted by ULISVNU (which stands for the University of Languages and International Studies under

1 This research has been completed under the project No KHCN-TB.26X/13-18

* Tel.: 84-965746666

Email: nguyen.ngocluuly@yahoo.fr
Vietnam National University, Hanoi) under the Program "Science and Technology for sustainable development of the Northwest" coded KHCN-TB/13-18 aims to develop an appropriate model for enhancing foreign language proficiency for public officials, civil servants and public employees in Northwest provinces of Vietnam. Such development of an effective foreign language curriculum or model involves many factors that need to be carefully considered by curriculum designers. The authors consider the most important factor being the identification of an appropriate approach, as this is the guideline controlling 
the operation, content of textbooks and learning materials, amongst others.

\section{The selection of learner autonomy-based approach}

Considering the current situation of foreign language proficiency, the demand for enhancing foreign language proficiency, the requirements and conditions of public service delivery by public officials, civil servants and public employees, new viewpoints on foreign language proficiency enhancement models from inside and outside the country, the feasibility and effectiveness of teaching methods in Vietnam, the authors reckon that "learner autonomy-based approach" is the most appropriate for the following reasons:

Firstly, through our own observation, we find that traditional Vietnamese education is still oriented towards "good student, good child" thinking, which aims at training students who rigidly follow examples with little creativity and innovation. This, inter alia, we believe, results in Vietnam's low productivity compared to that of other countries in the region. Training, retraining, improvement and self-improvement are not considered inevitable trends. Generally, teachers prioritise learners' acquisition of bookish knowledge from textbooks rather than focusing on helping learners to be confident, inspiring learners to figure out meanings for their life and work, and adding values to society. The teaching and learning of foreign languages in Vietnam are in the same situation. Foreign language teachers tend to use imported textbooks, and closely follow their content, which may not all be relevant to Vietnamese learners' interest. Teachers may not pay due attention to and spend sufficient time on learners' psychology and needs; nor do they instruct learners to do self-directed learning, construct learners' profiles, develop a learning roadmap for each of them. They do not pay attention to learners' use of foreign languages at work to give comments and feedback, either. Thus, in order to support public officials, civil servants and public employees, firstly there should be a big transformation to change perceptions and habits of teachers and learners about the learning process towards more selfdiscipline to make the learning process become more effective and better meet the demand of using foreign languages in delivering public services.

Secondly, learning materials play a very important role, and must be specific to each group of learners. Therefore, the crucial point is developing learning materials that can meet learners' demand of using foreign languages. The development of learning materials these days cannot be separated from, or fail to make use of, advances in information technology, as this is an inescapable trend in foreign language education. Authentic materials from sources such as the Internet, television and radio are trustworthy and accurate materials to help learners get familiar with the native use of foreign languages. Besides, learning materials which are developed specifically for the purpose of enhancing foreign language proficiency are also encouraged if they are carefully designed to meet the demand of learners as they can assist learners at work.

Thirdly, the theory and practice of autonomy always attach great importance to learners' psychology; teachers' organisation and management skills; the needs for learning environment and learning materials; the application of modern technology to optimise the effectiveness of the learning process. Therefore, this approach is appropriate for fixing issues as analyses of surveys on proficiency and demand of foreign languages of public officials, civil servants and public employees have revealed. 
2. Review of learner autonomy models in foreign language education

When researching and reviewing learner autonomy models, the authors pay attention to those which are highly applicable to learners who study in foreign language classrooms, adult learners who want to use foreign languages in delivering public services; models that can contribute to forming the solid foundation for implementing learner autonomy development strategies effectively in various contexts, especially in developing countries. For each model, the authors study the approach, outline specific features and extensively developed aspects, and analyse the applicability of the model to the enhancement of foreign language proficiency for Vietnam's public officials, civil servants and public employees. In the following part, the authors review models that are deemed most suitable for Vietnam's conditions and adult learners who want to improve their foreign language proficiency at work. Models are presented in chronological order according to the time they were introduced by researchers.

\section{Nunan's model (1996)}

Nunan mostly pays attention to the 'content' and 'process' of language teaching and learning. He proposes a five-level model of 'learner action', consisting of 'awareness', 'involvement', 'intervention', 'creation' and 'transcendence'. Nunan's model, which is perceived as a spectrum, suggests that the development of the learner takes place between 'awareness" (the left side of the spectrum) where learners start by acquiring knowledge of concepts and then gradually move towards 'transcendence' (the right side of the spectrum). At the awareness level, learners would be made aware of pedagogical goals and contents of materials as well as identify strategy implication of pedagogical tasks and learning styles and then identify their favourite learning styles and strategies. The 'involvement', 'intervention', and 'creation' levels help learners continue to practice this knowledge. This is the trialand-error process for adjustment and gaining experience to help learners become more autonomous. At the 'involvement' level, learners only follow instructions while at the 'intervention' level, learners would propose their own ideas. 'Creation' is a higher level. At the 'transcendence' level, learners would make links between the content learnt in the classroom and the outside world, and they would become teachers, researchers, and the like. They would use language exquisitely to achieve success in work and life. Autonomy indicates the ability of learners to take responsibility for their own learning. Extending perspectives of autonomy to any broader contexts, it seems that the concept of autonomy indicates a higher-level goal, making autonomy a greater generalised individuals' attributes. In the authors' viewpoint, Nunan's model focuses on learners' perspectives, and is appropriate to be used in language teaching and learning. This model also helps learners become aware of where they are in the language acquisition process. Besides, this model can help educators and foreign language teachers design the most appropriate testing and assessment methods.

\section{Littlewood's model (1997)}

Littlewood expects that a detailed explanation on how autonomy develops in a language learner is made through the language learning process. He expands the view beyond the limit of language acquisition and attempts to distinguish three types of autonomy: autonomy as a communicator (aims to develop students' ability to use the language to communicate in real situations); autonomy as a learner (aims to develop students' ability to choose and apply meaning strategies to real situations); and autonomy as a person (aims to develop learners' ability to communicate, study and work independently; and develop greater generalised autonomy as individuals). With this 
approach, Littlewood's model is appropriate for developing projects on enhancing language proficiency for adult learners who have stable employment; along with clear and specific purposes of language use. The role of learners in the society help project developers clearly identify the foundation and role of learners in the language learning process as well as determining which factors learners already have and which factors they do not have yet in order to use language to do their jobs most effectively.

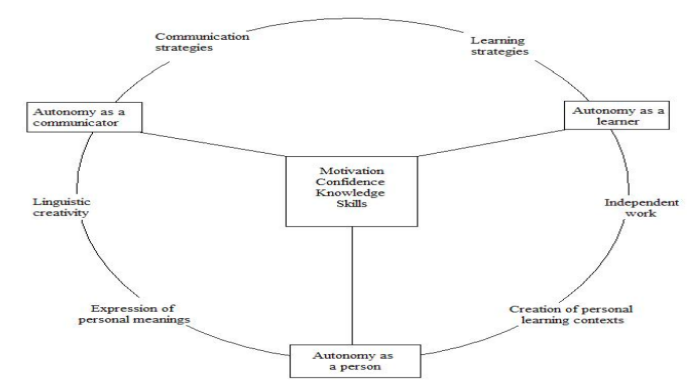

Figure 1. Developing autonomy through teaching (Littlewood, 1997: 83)

The figure contains four components: motivation, confidence, knowledge and skills, which contribute to a learner' willingness and ability to act independently and help them gradually become "communicator", "learner", and "person". The six additional labels around the circle including communication strategies, learning strategies, linguistics creativity, independent work, expression of personal meanings, creation of personal learning contexts show some of the concrete ways to express the three kinds of autonomy in learning. Each way is placed next to the kind of autonomy to which it most closely relates, e.g. expressing linguistic creativity by the creative use of language and/ or employing communication strategies in order to convey meanings; demonstrating and developing language learners' independence as communicators; applying personal learning strategies and/or engaging in independent work to demonstrate and develop ability as independent learners; creating personal learning contexts and/or expressing personal meanings to demonstrate and develop autonomy.

In his study on autonomy, Littlewood proposes an autonomy model that is used not only for language teaching and learning, but also for learning strategies in general and aiming to developing individual as members of society. Therefore, this model can help educators identify important factors in the implementation of projects on developing foreign language proficiency for public officials who need to enhance their language proficiency to do their jobs.

This three-stage model has another advantage, that is the distinction between 'proactive autonomy'- which affirms learners' individuality and sets up directions which they themselves have partially created, and 'reactive autonomy'- which does not create its own directions but, once a direction has been initiated, enables learners to organise their resources autonomously in order to reach their goals. As learners of the Project are individuals who have permanent jobs and clear goals of using foreign language to do their jobs, they already possess some attributes to acquire foreign language that others do not have. Thus, Littlewood's model is very appropriate for them. The Project developers can analyse and exploit this model to concentrate on important tasks that need to be carried out in order to support public officials, civil servants and public employees learning foreign languages in the most appropriate and effective way.

\section{Scharle and Szabo's model (2000)}

Scharle and Szabo propose another threephrase model consisting of 'raising awareness', 'changing attitudes' and 'transferring roles'. They published a landmark book for the development of autonomy named Learner Autonomy: A Guide to Developing Learner Responsibility. This model of learner 
autonomy involves dimensions that relate to the control over the language learning and teaching processes. These dimensions are learning management, cognitive processing and the content of learning. This model is similar to Nunan's model in terms of content and form; however, it is simplified for easier comprehension and better application. The biggest advantage of this model is that it can be used as guideline for educators and teachers in designing interactive activities for learners. The book provides suggestions and even sample activities for each phrase of the model; for example, opinion sharing, awareness of the learning process, identification of difficulties, self-correction, or self-evaluation. Teachers can use these sample activities, or base on them to design other activities that are suitable for their learners and their teaching conditions. Nunan's and Scharle's models share similar viewpoints but they are based on different approaches. The two models are constructed for learners of English in Asian countries, where English is a foreign language, not a second one. Nunan's model can support teachers in helping learners become aware of where they are in language acquisition as well as designing relevant testing and assessment instruments. Scharle and Szabo's model can support teachers in designing interactive activities for learners.

Blidi's study (2017)

The recent study of Blidi does not introduce any specific model; instead, it discusses five influential factors in developing and fostering learner autonomy. Voluntariness is the first factor that plays a role in enhancing or inhibiting learners' perception and attitudes to learner autonomy. Through this action research, Blidi suggests that in some cases compulsion might emerge as a necessary initial stage, part of the preparation work to develop learner autonomy and, primarily, to overcome some cultural and psychological hindrance, such as shyness, hesitation, and lack of self-confidence, which have a negative impact on learner's readiness and willingness to develop autonomy. The second factor is learner choice of learning tasks, pace, location and related conditions, which is perceived as central in directing learners towards embracing learner autonomy. Lee (1997) stresses learner choice as essential to autonomous learning. Holec (1981) perceives learner autonomy as an exercise of learning that involves making decisions. Lennon (2012) claims that successful teachers offer learners "freedom to learn in their own way" regardless of rigid curricula and textbooks. Teachers need to design open tasks, recommend suitable learning activities, or encourage and suggest learners to relate lessons to their personal interests, etc. These facilitate learners' practice of making choice and making decision, which inspire and foster autonomy. The third factor is flexibility, which is important to establish a supportive environment that facilitates and fosters learner autonomy. This is in line with learners' need to identify learning opportunities available for them. The relationship that the teacher establishes with learners, supporting and guiding them in their learning, plays a crucial role in fostering autonomy. The fourth factor is teacher's role. In fact, teachers need to embrace a supportive role as a facilitator who helps learners formulate their goals more clearly, and provides feedback, encouragement and reinforcement. The teacher facilitates the process of re-orientation and personal discovery. The fifth factor is peer support. Being autonomous and self-directed does not necessarily mean discarding peer support; instead, collaboration brings better results, as working in teams easily create motivation and inspiration for young learners who always have the need to prove themselves and get 
recognition. Teachers can base on Blidi's judgement and conclusion to guarantee that their activities aim at supporting learners to develop their inner force and optimise their existing foreign language proficiency and choose the learning and practice of language skills and knowledge to best suit their jobs.

\section{Discussion of the application of an} appropriate model to develop and deploy a foreign language proficiency enhancement model for Vietnam's public officials, civil servants and public employees

The above analysis and judgement show that the models and components of "learner autonomy" do not exclude each other. These modelsallvaluelearners'awareness and attitudes, which form the first essential stage. Nunan, Scharle and Szabo use the term awareness. Littlewood further specifies that the key factors in awareness are motivation and confidence. Meanwhile, Blidi stresses voluntariness. The terms may be used differently; however, they all refer to the readiness of learners and consider it the most important factor that need to be activated by teachers to help learners get into an appropriate state of mind. Each component has its contributions. The models are flexible and encourage gradual development of learner autonomy.

Besides, the models help readers figure out the changing roles of teachers and learners in the teaching and learning process. The perceptions of teachers and learners need to be changed. Teachers gradually "let go" of control; their job is organising, guiding, counselling, suggesting, regulating, comforting, and encouraging learners. In order to do so, teachers need to spend time guiding learners to develop self-directed learning, planning their teaching, organising activities, meeting learners, and collaborating with colleagues. Learners make progress and demonstrate their independence by creating opportunities to put the knowledge and skills they learn into practice; understand themselves and what they want to achieve. The principle of 'Teach Less, Learn More', which has transformed Singapore's education only in one generation, has not been adequately recognised in Vietnam. Teaching less does not mean working less; rather, it means lessons need to be carefully designed to help learners (who are public officials, civil servants, public employees with experience and clear learning goals) use foreign language to improve their work efficiency. Learner autonomy models can help learners study better and improve themselves. In order to achieve this, teachers need to study different contexts, teaching conditions, the mind and need of learners; spend time and effort designing and organising class activities to best facilitate learners.

Each model has its own distinct features depending on the authors' interest in certain aspects. For instance, Blidi (2017) stresses the importance of peer support; Aston (1996) and Reinders (2011) focus on the important role of learning environment and learning materials; while others focus on rearrangement of content, practical skills, testing and assessment which are suitable for autonomybased approach. This is understandable as learners in different contexts and learning environments have different attributes, needs, conditions and contexts. Nunan (1996) claims that 'the choice of model is dependent on teaching and learning environment'. This is one important thing to be considered when applying learner autonomy models.

\section{Littlewood's model}

In the context of establishing foreign language proficiency development model for public officials, civil servants and public 
employees in Vietnam, Littlewood's model of developing autonomy through teaching is the most appropriate for the following reasons:

Firstly, Littlewood provides a general overview, expands the view beyond the limit of language acquisition and attempts to distinguish three types of autonomy: autonomy as a communicator, autonomy as a learner and autonomy as a person. For each social role, learners need a different type of support to improve themselves. Littlewood's model helps identify the roles of learners in society, and their mission and goals for each role. This identification helps the Project developers know exactly the hierarchy of tasks that need to be done to help learners use language effectively in doing their jobs. For example, considering two factors contributing to an autonomous communicator, which are communication strategies and language creation, learners who are public employees already have good communication strategies thanks to their work experience; however, they have difficulty with language creation as their foreign language have not been exploited to communicate at office. Therefore, Littlewood's model is appropriate in the initial stages of the Project as they already have professional competence, background knowledge, and certain understanding of language learning. In the figure designed by Littlewood, each component of the figure can be referenced to factors that need to be developed or consolidated, therefore the figure can be the guideline for developing the project.

Secondly, this model consists of key factors of the learner autonomy-based approach to develop learners' language proficiency, create learners' voluntariness and independence and value awareness through stimulating "motivation" and boosting "confidence" for learners. This model has a similar approach to that of other learner autonomy models and can be combined with other models in different stages of the Project.

Thirdly, besides raising awareness through stimulating motivation and boosting confidence for learners, the two factors that have been mentioned in Littlewood's figure are knowledge and skills. Littlewood claims that if knowledge can meet the demand of learners, it can be acquired more effectively. Therefore, teaching should be tailor-made, and learners should be allowed to choose relevant learning tasks. With this approach, necessary skills to complete learning tasks are practised and sharpened.

\section{Other models}

In the next stage, when carrying out experiments with specific classes, the model of Scharle and Szabo is more detailed, helping educators or teachers working directly with learners know necessary skills, and steps to help learners become independent, autonomous in their learning strategies; discover and exploit appropriate learning materials; practise skills to gain knowledge and form habits with new methods; aim at sustainable learning and lifelong learning. This model is appropriate for teachers who directly organise classes because it helps them pursue clear objectives in each learning phase. Then educators and teachers can adjust activities to make them relevant to these objectives.

In conclusion, while Littlewood's model can be the guideline deciding the hierarchy of priorities for project developers to work on tasks that need to be done as well as the amount of each task, Scharle and Szabo's model help teachers who carry out experiments in classes or who directly teach classes organise their activities and instruct learners to follow directions in their activities. In the application of models into developing 
interactive activities in class, and organising classes, educators and teachers need to pay attention to influential factors, such as Blidi's factor of peer collaboration, or Nunan's factor of self-awareness in order to implement models effectively.

4. Factors fostering learner autonomy in foreign language proficiency enhancement model for public officials, civil servants, and public employees in Vietnam

When planning and developing foreign language proficiency enhancement models, based on approaches of different models which have been selected and used in different phrases of the Project, the authors analyse and synthesise the following main factors that need to be considered when implement the learner autonomy-based project.

\section{Enhancing learners' motivation}

Nunan (1996), Littlewood (1997), Scharle and Szabo (2000), Blidi (2017) who propose models for developing learner autonomy, share one viewpoint that learner autonomy is a cognitive category that depends on learners' motivation and preference. Therefore, stimulating 'motivation' is the number one condition to help learners 'voluntarily' participate in learning activities. In order to achieve that, some researchers suggest doing the following things: observe and listen to learners, research and explore topics that interest students and develop those topics instead of rigidly following themes in textbooks. Lennon (2012) suggests teachers providing students with a list of tasks for them to choose, as he claims successful teachers are those letting students have the 'freedom to study in their own way' regardless of rigid curricula and textbooks. James Chapman (2015), through a number of quantitative studies, proves the failure of constructivist approach and 'one-size-fits-all' approach. He suggests the use of 'differentiated instruction' for learners to make sure that learners are supported timely and appropriately, thus helping them to connect to lessons and achieve optimal effectiveness within their capacity.

\section{Boosting learners' confidence}

In the figure of developing learner autonomy through teaching, Littlewood (1997) mentions four components in developing voluntariness and independence, they are: motivation, confidence, knowledge, and skills. Apart from motivation, confidence in also very important to language learning. However, many of Vietnam's public officials, civils servants and public employees receive an education that focuses on theoretical knowledge, embraces passive learning and prioritises achievement for years, resulting in a lot of knowledge learnt at schools ending up being useless. Therefore, they do not have confidence in learning foreign languages. Teachers should help learners overcome psychological barriers; encourage them to use foreign languages to talk about topics of their interests (e.g. projects for professional development, or relevant employment contracts, etc); assign them specific tasks that require thinking to conduct and ask them to create tangible products. Thus, language is only a tool to convey ideas or share the work that learners care about. Learners would present what they create wholeheartedly. The pride in presenting their forte helps them become more confident and ignore their reserve in learning foreign languages.

\section{Innovating teaching content}

Knowledge plays the key role in teachers' lectures. However, teachers often closely follow the imported textbooks; while in language teaching, it is not advisable to be dependent on only one source, especially when imported textbooks often cater for different learners' background and needs. It is understood that if background knowledge 
can meet the demand of learners, it can be acquired more effectively. Therefore, teaching should be tailor-made, allowing learners to choose appropriate learning tasks. It is important to pay attention to content and topics that are relevant to learners' age instead of focusing on linguistic aspects such as phonetics, grammar, vocabulary. Teachers' understanding of learners and proactive search influence the choice of learning content. For example, Vietnam's public officials, civil servants and public employees can extent their vision, develop critical thinking skills in doing activities and their jobs if teacher engage them in carrying out activities with authentic materials such as reading books, watching news reports about their jobs done by native speakers instead of focusing only on textbooks. Gradually, they acquire the habit of using foreign languages as a tool for searching, thinking, communicating and cooperating, not just to study grammar without content.

\section{Practising skills associated with practical tasks}

During the course of performing tasks, necessary skills are practised and fostered. The skills include not only reading, writing, listening, speaking, but also social skills that are necessary for fulfilling required learning tasks. So, developing proficiency in general is done alongside developing language skills because this helps learners to use critical thinking skills to solve problems inside and outside classroom, as well as practise necessary skills.

\section{Guiding self-directed learning}

In this context, teachers organise, instruct, counsel, suggest, control, comfort, and encourage groups of learners. In order to do so, teachers need to spend some time guiding learners to do self-directed learning; and teachers themselves need to study. In Finland, teachers "teach less" and spend more time planning their teaching, meeting learners, collaborating with colleagues, adjusting and suggesting learning products for learners (Hargreaves, 2012). As long as Vietnamese people still hold stereotypes about unconventional teaching methods, teachers do not want to leave their "comfort zone" to help learners gain valuable things and develop the national education.

\section{The "letting go" of teachers}

Teacher should empower learners to foster learner autonomy. Kirschner and Merriënboer (2013) suggest that controlling learners' learning should be considered carefully based on their proficiency. The authors consider this the guideline for teachers to be "wiser" in helping learners foster learner autonomy, deciding when to intervene, when to support, and when to let learners search for themselves. In these cases, the borderline is quite thin. Teachers with their interpersonal experience, pedagogical knowledge, and the wish to improve quality of teaching, would gain more experience in diverse situations thanks to the teaching and practice with learners. These above studies show that the amount of "letting go" and "creativity" helps learners develop motivation for learning and move forward.

\section{Testing and assessment}

Apart from testing four skills, which are listening, speaking, reading and writing after each stage, it is also important for teachers to be instructed to create and update learners' portfolios and learning roadmap. Due to the fact that language learning is associated with tasks, teachers should assess learners' products based on general proficiency framework besides foreign language proficiency framework. Thus, learners can be aware of what they need to do to produce better projects, what skills they need to practise to accomplish tasks better, what attitude they need to adopt to cooperate better. These 
help learners use foreign languages more effectively in their jobs and life. However, this is an unprecedented task; thus teachers can encounter various difficulties, especially those who do not work in the same professional field as learners. In this case, the passion for learning, dynamic teaching and learning styles can lead to fundamental and effective changes in testing and assessment, which holds the key to support learners to be more independent and autonomous in searching for information and seeking practice opportunities for themselves.

\section{Peer support}

The current teaching approach values the role of "group of learners" and collaboration among them instead of "learners" (Dam, 1995; Blidi, 2017). The researchers claim that autonomous learning does not mean individual learning without peer support. When the whole group or class do things together to achieve the same goal, young learners are encouraged and inspired as they always have the need to prove themselves and get recognition. Teachers should give learners opportunities to cooperate with each other, share their learning strategies, learning products as well as new ideas.

\section{Establish learning environment beyond classroom}

Language learning is no longer restricted to classroom environment. Learning environment which is beyond classroom environment facilitates teachers and learners in designing creative activities and tasks instead of ordinary textbook activities, and facilitating autonomybased tasks such as: writing daily work journals in foreign languages, summarising workrelated materials or carrying out role-play, developing the habit of listening and reading in foreign language beyond classroom; forming forums; making connection with foreign partners, participating in projects promoting the development of learning materials or the use of foreign languages; joining foreign language community, etc.

Developing diverse and appropriate learning materials, taking advantage of information technology in language teaching and learning

Apart from an open learning environment, learning materials need to be appropriately designed to create optimal effectiveness for learners. Designing and developing learning materials for autonomous learning is really time-consuming and challenging, especially in the early stages. Learning materials that are available in markets many not be appropriate, and for some teachers this kind of material is a totally new experience. Reinders (2011), in his study on developing learning materials beyond classroom, concludes that "Teachers can find complete satisfaction in knowing that the final result will help their learners improve not only their language skills, but also their lifelong learning skills". Many educators such as Aston (1996) and Littlejohn (1997) encourage learners to take part in materials creation.

\section{Conclusion}

The analysis offers key findings, principles and guidelines to the development of foreign language proficiency enhancement model for public officials, civil servants and public employees from the stage of applying models to plan relevant tasks to the stage of applying the model and factors contributing to fostering of learner autonomy in a specific pilot class for public officials, civil servants, and public employees in Vietnam. Then educators and teacher can organise activities and gain experience in order to help learners study effectively. With the autonomy-based approach in foreign language education, an open learning environment with diverse and appropriate learning materials facilitates the creation of creative learning activities and tasks 
and fulfilment of tasks. In implementing this, teachers' organization and guidance as well as peers' collaboration would help learners achieve autonomy and gain experience, as acknowledged in various theoretical and empirical studies.

\section{References}

Aston, G. (1996). The learner's contribution to the self-access centre. In T. Hedge \& N. Whitney (Eds.), Power, Pedagogy \& Practice (pp. 283293). Oxford: Oxford University Press.

Blidi, S. (2017). Collaborative learner autonomy, a model of learner autonomy development. Singapore: Springer.

Chapman, J.W. (2015). Learner Autonomy: When Philosophy Meets Pedagogy. Invited keynote presentation for the $7^{\text {th }}$ COTEFL Conference, Purwokerto, Indonesia.

Dam, L. (1995). From theory to classroom practice: Learner Autonomy. Dublin: Authentik.

Hargreaves, A. \& Shirley, D. (2012). The global fourth way, The quest for educational excellence. USA: Corwin.

Kirschner, P.A., \& van Merriënboer, J.J.G. (2013). Do learners really know best? Urban legends in education. Educational Psychologist, 48(3), 169-183.
Lennon, P. (2012). Learner Autonomy in the English Classroom: Empirical Studies and Ideas for Teachers. Frankfurt am Main: Peter Lang AG.

Littlejohn, A. (1997). Language learning tasks and education. English teaching professional, 6, p.190. http://www.andrewlittlejohn.net/website/ art/arthome.html

Littlewood, W. (1997). Self-access work and curriculum ideologies. In P. Benson and P. Voller (Eds.), Autonomy and independence in language learning. London: Longman.

Nunan, D. (1996). Second Language Teaching and Learning. Florence: Heinle\&Heinle Publishers.

Reinders, H. (2011). Materials Development for learning beyond the classroom. In Phil Benson and Hayo Reinders (Eds.) Beyond the classroom. London: Palgrave Macmillan.

Sahlberg (2010). Finnish lessons: What can the World Learn from Educational Change in Finland? (Series on School Reform). New York: Teachers College Press, Columbia University.

Scharle, A. \& Szabo, A. (2000). Learner Autonomy: A Guide to Developing Learner Responsibility. Cambridge Handbooks for Language Teachers, Series editor for Penny Ur.

\title{
XÂY DỬNG MÔ HÌNH NÂNG CAO NĂNG LỬC NGOAI NGỬ CHO ĐỘI NGŨ CÁN BỔ, CÔNG CHÚC CÀ VIỂ CHỨC VIẸT NAM THEO HƯỚNG TIẾP CẬN TỰ CHỦ
}

\author{
Nguyễn Ngọc Lưu Ly \\ Khoa Ngôn ngũ và Văn hóa Pháp, Truờng Đại học Ngoại ngũu, ĐHQGHN, \\ Phạm Văn Đồng, Cầu Giấy, Hà Nội, Việt Nam
}

Tóm tắt: Tính tự chủ là một chủ đề được đông đảo giới khoa học các nước quan tâm, nghiên cứu và áp dụng. Bài viết đã lý giải việc lựa chọn, phân tích đánh giá và triển khai mô hình phát triển tính tự chủ phù hợp để hỗ trợ đội ngũ cán bộ, công chức và viên chức Việt Nam lĩnh hội và làm chủ ngoại ngữ. Bài viết cũng cung cấp một số giải pháp nhằm nâng cao năng lực ngoại ngũ cho đội ngũ này trong bối cảnh cần đồi mới phương pháp dạy học ngoại ngữ chất lượng hơn để có thể sử dụng hiệu quả trong công việc.

Tù khóa: mô hình, năng lực ngoại ngữ, tự chủ, cán bộ, công chức, viên chức 